\title{
Review study on antibacterial activity of cherry leaf (Muntingia cala- bura) against Staphylococcus spp. and Salmonella spp. the most causing disease in livestock
}

\author{
Galuh Dianita Fitri, Heli Tistiana and Lilik Eka Radiati \\ Faculty of Animal Husbandry, Brawijaya University \\ Jl. Veteran Malang 65145, Malang City, East Java, Indonesia \\ Correspondent author: galuhfitri95@gmail.com
}

\begin{abstract}
This research was conducted to know the potential activity of cherry leaf (Muntingia calabura) as an alternative medicine for diseases caused by the bacteria Staphylococcus spp. and Salmonella spp. The material of this study used some literature which relates to the paper's topic. The descriptive method was used to explain and describe the findings in the discussion chapter. A study of the effectiveness of the cherry leaf (Muntingia calabura) was made with other natural antibacterial sources such as sirih leaf (Piper betle L.) and beluntas leaf (Pluchea indica L.). The result of this study showed that cherry leaf extract was an effective natural antibacterial source because it had the widest inhibited zone against Staphylococcus spp. and Salmonella spp. which amounted to (19 $\mathrm{mm}$ and $37.7 \mathrm{~mm}$ respectively) as compared to beluntas leaf ( $9.5 \mathrm{~mm}$ and $15.9 \mathrm{~mm}$ respectively) and sirih leaf (16 $\mathrm{mm}$ and $17 \mathrm{~mm}$ respectively). The other significant result showed that Muntingia calabura was effective for duck egg hatchability which amounted to $87.74 \%$. This result was higher than chemical antibacterial $(80.81 \%)$, beluntas leaf $(44.05 \%)$ and sirih leaf $(46.43 \%)$. From all the literature reviewed about widest inhibited zone of natural antibacterial activity such as cherry leaf, beluntas leaf and sirih leaf against Salmonella spp. and Staphylococcus sp, the same extraction treatment was used. The result from the duck egg hatchery experiment between chemical antibacterial and natural antibacterial showed that they have the same treatment and effect on duck egg incubation time. It is suggested that further research is conducted to find out if the cherry leaf can be used as an alternative natural antibacterial for diseases caused by other bacteria.
\end{abstract}

Keywords: antibacterial, chemical, natural, cherry leaf, bacteria

\section{INTRODUCTION}

Food consumption is increasing each passing year rapidly due to increasing world population. Badan Pusat Statistik (2015) reported that most of the animal product consumption increase happened in 2014 and 2015. Although the demand for animal products is on the rise, this country still has a low level of consumption compared with other nations. As explained by Chandra (2016), one good example is Indonesia in 2016 where beef meat consumption was only at $2.61 \mathrm{~kg} / \mathrm{GDP}$, a meager amount compared with Argentina which consumed $55 \mathrm{~kg} / \mathrm{GDP}$. The existing imbalance between supply and demand of animal products has a significant effect on the consumption rate of the Indonesian people. This implies that this country must increase the livestock population to increase the 
GDP (Gross Domestic Product) in the livestock sector.

There are two types of factors that have been affecting livestock conditions; external and internal. As Johnson et al., (2016) has found out, external factors that can affect animal production are farm size and technology adaptation on the farm whereas internal elements can be disease handling techniques and genetic composition.

According to Budiharta and Warudju (1985), Staphylococcus aureus causes mastitis (a livestock disease in dairy cows), and farmers apply chemical antibacterial to heal that disease. In 2015, Kementrian Kesehatan Republik Indonesia (Ministry of Health Indonesia) suggested that Staphylococcus aureus should be included in the category of multiresistance bacteria. The WHO also reported in 2016 that there were 480.000 new cases of multidrug resistance in the world. This means that antimicrobial resistance is a serious problem. Kemal (2014) reported the effect of Salmonella spp. infection as being dangerous. Some of the targets of the bacteria are in the digestive tract and reproductive tract. This makes the animals sick and decreases the farmer's income. For example, Salmonella typhimurium causes abortion in cattle, sheep, and horses. This means that bacteria interrupts the replacement cycle of livestock on a farm and with this, the farmer cannot fulfil the consumers' needs (as there is an imbalance between demand and what the farmer can supply). Besides the effect on the internal composition of affected livestock, the bacteria can be spread by the air to affect other animals.

Based on this explanation, there is the need for a natural better to substitute the chemical antibacterial. One of the potential tropical plants which can be used as a natural antibacterial is the cherry leaf (Muntingia calabura). The major benefit of the natural anti-bacteria is that it does not show significant side effects on the test subject. This review study intends to assist the farmer with one of the best natural antibacterials that can be used to increase livestock productivity which will in turn automatically raise the farmer's income.

\section{RESULTS AND DISCUSSION}

\section{Livestock farming in Indonesia}

The development of livestock farming in Indonesia has been increasing every year. The farm products commonly consumed by Indonesian people come mainly from cattle, poultry, swine, and ducks. Nevertheless, according to Direktorat Jenderal Peternakan dan Kesehatan Hewan (2016) livestock population increased in previous years but not significantly. For example, the broiler population in 2015 was $1,528,329$ heads, and this number rose to $1,592,669$ heads in 2016 . There was an increase of only 64,360 heads in one year equivalent to $4.21 \%$. Factors that affect livestock population can be grouped into 'external' and 'internal'. External factors that affect livestock population include weather, diseases, and parasites which all influence livestock productivity. Internal factors include adaptation, nutritional practices, disease handling and adaptation to diet.

Indonesia is located in South East Asia and having tropical weather, many diseases affecting livestock health and productivity occur in the country. Common diseases which attack livestock are endemic to the tropics. Endemic parasites which cause the diseases are a major source of economic loss in animal husbandry and especially in tropical areas and developing countries, but as will be discussed later, the extent of those losses is yet to be accurately 


\begin{tabular}{lccccccc} 
& noid & & nins & & penes & & sides \\
\hline Cherry $^{\mathrm{a}}$ & +++ & ++ & +++ & + & - & + & ++ \\
Sirih $^{\mathrm{b}}$ & + & + & - & + & - & + & - \\
Beluntas $^{\mathrm{c}}$ & ++++ & ++ & + & +++ & - & ++++ & ++ \\
\hline
\end{tabular}

+ : Constituents present in little amounts; ++: Constituents present in moderate amounts; +++ : Constituents present in abundance; - : Constituents not detected.

Source:

$\mathrm{a}=$ Buhian, et.al., 2016

$\mathrm{b}=$ Sangi, et al., 2008 .

$\mathrm{c}=$ Widyawati and Budiant, 2014

Some of the factors affecting the results were the kind of leaf, the type of plant, plant location, local climate, genetics of the plant and weather when the research was performed. The following table shows whether each natural antibacterial source had an active antibacterial compound. After identifying each active compound on the cherry leaf (Muntingia calabura), sirih leaf (Piper betle Linn) and beluntas leaf (Pluchea indica $L$.) here is the Table 2 explaining effectiveness from each leaf to its bacterial activity.

Table 2. The comparison of inhibited zone from natural antibacterial against Salmonella typhimurium and Staphylococcus aureus.

\begin{tabular}{lcc}
\hline \multirow{2}{*}{$\begin{array}{c}\text { Natural } \\
\text { antibacterial } \\
\text { extract }\end{array}$} & \multicolumn{2}{c}{ Inhibited zone $(\mathrm{mm})$ on bacteria } \\
\cline { 2 - 3 } & Staphylococcus aureus & Salmonella typhimurium \\
\hline Cherry leaf & $37.7^{\mathrm{a}}$ & $19^{\mathrm{a}}$ \\
Beluntas leaf & $15.9^{\mathrm{c}}$ & $9.5^{\mathrm{b}}$ \\
Sirih leaf**** & $17^{\mathrm{d}}$ & $16^{\mathrm{d}}$ \\
\hline
\end{tabular}

Source:

$\mathrm{a}=$ Buhian et.al., 2016

$\mathrm{b}=$ Nurhalimah et al., 2015

$\mathrm{c}=$ Manu, 2013

d = Madduluri et al., 2013

Cherry leaf was an effective natural antibacterial source because it had a larger inhibition zone $(37.7 \mathrm{~mm}$ and 19 $\mathrm{mm}$ ) which implied it occupied the "very strong" and "strong" category as compared with beluntas leaf (9.5 and $15.9 \mathrm{~mm})$ and sirih leaf (17 $\mathrm{mm}$ and 16 $\mathrm{mm})$. Another reason as to why Muntingia calaburawas more efficient in destroying bacterial cells was because as indicated in Table 1 this leaf had more constituent saponins (+++). Saponins were observed to destroy the bacterial cell wall and opened the way for other active compounds gain entry into the bacterial cell. The more the saponins, the easier antibacterial can enter into the bacteria cell. This was another improvement to the results shown in Table 2 with each leaf tested with the same method of extraction by ethanol. Table 3 offers a further explanation about inhibition zones 
Tabel 3. Antimicrobial inhibition zone category

\begin{tabular}{ll}
\hline Diameter $(\mathrm{mm})$ & Growth of inhibit response \\
\hline$>20$ & Very strong \\
$10-20$ & Strong \\
$5-10$ & Medium \\
$<5$ & Weak \\
\hline
\end{tabular}

Source: Mahardika et al., 2014

The results of the inhibition zone from leaf extracts in Table 2 compared with results in Table 3 means each natural antibacterial shows effectiveness against Staphylococcus aureus. Cherry leaf was shown to be very strong; beluntas leaf was also strong as was sirih leaf. When it came to the inhibition zone of natural antibacterials against Salmonella typhimurium, results showed thatchery leaf was very strong, beluntas leaf occupied showed medium strength, and sirih leaf was also strong. The inhibited zone was used as a parameter to measure the effects of the purported antibacterial or antimicrobial against bacteria or microbes. Another case in a hatchery farm was the case of egg shells infected by Staphylococcus aureus and Salmonella spp.

Usually, farmers in Indonesia used chemical antibacterial to solve the problem. In this research, a comparison between synthetic antibacterial and natural antibacterial on egg hatchability and mortality shows that a natural approach is better than an artificial one. To prove that natural antibacterial also had the ability to solve the problem in the hatchery farm, Table 4 elaborates further.

Table 4. The amount of hatchability and mortality on duck egg with chemical antibacterial and natural antibacterial.

\begin{tabular}{lcc}
\hline Antibacterial & Hatchability (\%) & $\begin{array}{c}\text { Mortality } \\
(\%)\end{array}$ \\
\hline Chemical antibacterial $^{\mathrm{a}}$ & 80.81 & 18.87 \\
Cherry leaves extract $^{\mathrm{a}}$ & 87.74 & 12.26 \\
Beluntas leaves extract $^{\mathrm{b}}$ & 44.05 & 55.95 \\
Sirih leaves extract $^{\mathrm{c}}$ & 46.43 & 47.62 \\
\hline
\end{tabular}

Source:

$\mathrm{a}=$ Alkhakim et.al. (2016) duck egg

$\mathrm{b}=$ Zamzamy et al., 2014

$\mathrm{c}=$ Nandhra et al., 2015

From the table above, it can be concluded that from among plant leaves extract and other natural resources; cherry leaf can be used as an alternative natural antibacterial in place of chemical antibacterial. Cherry leaf extract is more effective than other alternatives on hatchability amounting to $87.74 \%$ effectiveness. This result for efficiency was higher than chemical antibacterial
$(80.81 \%)$. Other natural antibacterials gave results as follows; Beluntas leaf $(44.05 \%)$ and Sirih leaf $(46.43 \%)$. This counted as low hatchability when compared with Cherry leaf.

Anderson (2012) mentioned that the bacteria Staphylococcus aureus and Salmonella spp. were commonly found in egg shells. Both of these bacteria cause failure of hatching through the 
death of the embryo (Soeripto and Poeloengan, 1991). Therefore, the disinfection process on hatching duck eggs should be done.

The process of egg hatching disinfection usually used formaldehyde or formalin as a disinfectant. Disinfectants can be fatal leading to the death embryos and increase abnormality when an excessive dose is used (Nandhra et al., 2015). This was confirmed by Zamzamy et al. (2015) who stated that disinfection with chemicals at low concentrations could not kill pathogenic bacteria on eggs, while when at too high concentrations, it can kill the embryo eggs. Therefore, it is necessary that herbal ingredients that can replace the function of formaldehyde as a disinfectant be used. Cherry leaf extract can slow down and kill pathogenic bacteria on eggs if used correctly.

\section{Mechanism of action of Muntingia- calabura against bacteria}

Extract of the cherry leaf was more effective on Staphylococcus aureus than Salmonella typhimurium. The reason for this result was that antibacterial readily attacks Gram-positive bacteria (Staphylococcus aureus) than gramnegative bacteria (Salmonella typhimurium) and also has a correlation with bacterial cell structure. The outer membrane of gram-negative bacteria acts as the entry barrier compounds where the cells are not needed, such as bacteriocins, enzymes, and compounds that are hydrophobic. The antimicrobial compounds can penetrate lipopolysaccharide (LPS) from the cell wall. Hydrophilic molecules find it easier to pass LPS compared with hydrophobic molecules. Gram-positive bacteria do not have LPS, and this means that the barrier function does not exist, and molecular antimicrobial compounds that are hydrophilic and hydrophobic (such as essential oils) can diffuse into such cells quickly (Ousallah et al., 2006).

The work of an antibacterial is divided in every bacterial cell part. The first section of the bacteria cell is the cell wall. The active compound which has a role in disturbing the bacteria cell wall is saponins because it destroys the cell wall and opens the way for other active compounds to gain entry into the bacterial cell. Turgor in the cell wall is disturbed by saponins, the effect of this interference makes the antibacterial compound to enter the bacterial cell quickly and then hampers the metabolism leading to the collapse of the bacterial cell wall. Saponins can damage bacteria cell membranes by increasing cell permeability then causing membrane proteins denaturation until lysis occurs and they are broken (Karlina et al., 2013; Johnsonet al.,2016; Ahmad et al., 2015).

The second part of the bacteria cell is the cell membrane. Steroids and flavonoids can damage this layer. Steroids kill the bacteria cell by destroying the plasma membrane of the microbial cell until it creates risk in the cytoplasm. The conditions needed for effect by steroid molecules are included in the non-polar (hydrophobic) and polar (hydrophilic) groups. This was a reason this active compound has surfactant effects that can dissolve phospholipid plasma membranes. According to Wiyanto (2010), the phospholipid is the dominant compound of the plasma membrane. Steroids inhibit the growth of bacteria such as Staphylococcus aureus, E. coli, Proteus vulgaris, Salmonella typhimurium, Klebsiella, Pneumonia dan Bacillus subtillis (Solomon et al., 2014; Retnowati et al., 2011). Flavonoids have three mechanisms that provide antibacterial effects. One is by inhibiting the synthesis of nucleic acids, 
the second is by inhibiting the function of the cytoplasmic membrane, and the third is by inhibiting the energy metabolism of the cell (Cushnie and Lamb, 2005). The bacteria that are exposed flavonoids will lose cell permeability. The cessation of metabolic activity will make bacterial cells die (Soedibyo, 2004; Kurniawan et al., 2013).

The third part in the bacterial cell is the cytoplasm. This is the most important part of the cell because it contains elements which bacteria need for survival. The cytoplasm is made up of proteins, amino acids, sugars, nucleotides, salts, vitamins, enzyme, DNA, ribosomes and internal bacterial structure that float around in the cytoplasm. The active compounds that can disturb cytoplasm are tannin, steroids, flavonoid, glycoside, and alkaloids. Flavonoids have a disinfectant effect and denature proteins which in turn cause a stop in the activity of bacterial cell metabolism. This condition happens because the enzyme (which is the protein) is catalyzed to all cell metabolism activity. Hydroxyl groups present in the structure of flavonoid compound cause changes in organic components and nutrients transport which will lead to toxic effects on bacteria (Sabir, 2005). These conditions may cause the death of a bacteria cell.

Tannin compound can inhibit protease enzyme activity, inhibit enzyme inside the sheath of bacterial cell transport leading to further destruction or inactivation of genetic material. More tannin can shrink the bacterial cell wall, destroying cell permeability and affecting cell growth and activities causing growth abnormality or the complete death of the bacteria cell (Mahardika et al., 2014; Ngajow et al., 2013). Glycoside has many functions including being an antibacterial, an anticancer and animmune-stimulant (Kusuma et al., 2005). Steroids can destroy bacteria cell membrane including the cytoplasm. The steroid molecule includes non-polar (hydrophobic) and polar (hydrophilic).These conditions make the active compound enter the cytoplasm easily (Wiyanto, 2010). The alkaloid componentis known as the DNA intercellulator, and it inhibits the bacterial cell topoisomerase enzyme (Karou et al., 2005; Mahanani et al., 2012; Retnowati et al., 2011). Topoisomerase is an enzyme for DNA replication, if this enzyme is interrupted, bacterial cells cannot reproduce.

\section{CONCLUSION}

Cherry leaf (Muntingia calabura) has the potential to be used as a natural antibacterial against Staphylococcus spp. and Salmonella spp. This plant is rarely used in Indonesian society. Based on the results of this review study, it is hoped that people in Indonesia will benefit by using cherry leaf as a natural antibacterial instead of chemical antibacterials.

\section{REFERENCES}

Ahmad, A., Kaleem, M., Ahmed, Z., and Shafiq, H. 2015. Therapeutic Potential Of Flavonoids And Their Mechanism of Action Against Microbial And Viral Infections - A review. xxx : 1-15. http://www.sciencedirect.com/sc ience/article/pii/S096399691530 0673.

Alkhakim, F.H., Huda, M.N., Fitri, G.D., Ambar, D and Tistiana, H. 2016. Pengaruh ekstrak daun kersen terhadap daya tetas dan mortalitas telur itik hibrida. 26(2):8-13. http://jiip.ub.ac.id/in 
dex.php/jiip/article/view/239/34

1.

Badan Pusat Statistik. Data konsumsi masyarakat 2015. https://www.bps.go.id/linkTabel Statis/view/id/950. Accesed on $1^{\text {st }}$ February 2017.

Budiharta, S and Warudju, B. 1985. Mastitis di Daerah Istimewa Yogyakarta. II Isolasi Bakteri Penyebab dan Resistensi terhadap beberapa antibiotika. Hemerazoa. 72(1):58-68. in Supar and Ariyanti, T. 2007. Kajian pengendalian mastitis subklinis pada sapi perah. Semiloka Nasional Prospek Industri Sapi Perah Menuju Perdagangan Bebas-2020. http:/peternakan. litbang.pertanian.litbang. pertanian.go.id/fullteks/ lokakarya/loksp08-50.pdf?sec cure $=1$.

Buhian, W.P.C., Rubio, R.O., Jr, V.D.L and Puzon, J.J.M. 2016. Bioactive metabolite profiles and antimicrobial activity of ethanolic extracts from Muntingia calabura L. leaves and stems. Asian Pac J Trop Biomed. 6(8): 682685.http://www.sciencedirect.co $\mathrm{m} /$ science/article/pii/S22211691 15310376.

Cushnie, T., Lamb A.J., 2005. Antimicrobial activity of flavonoids. International Journal of Antimicrobial Agents. 26 : $343-356$. http://www.idpublications.com/j ournals/PDFs/IJAA/ANTAGE_Mos tCited_1.pdf.

Chandra, A.A. 2016. Konsumsi Daging di Argentina $55 \mathrm{Kg} /$ Kapita, RI Cuma 2,61 Kg. https://finance.detik.com/ekono mi-bisnis/3150082/konsumsidaging-di-argentina-55-kg- kapita-ri-cuma-261-kg. Accesed on $1^{\text {st }}$ February 2017.

Kementrian Kesehatan Republik Indonesia. 2015. Pengggunaan antibiotik bijak danrasional kurangi beban penyakit infeksi. www.depkes.go.id/article/pengg gunaan-antibiotik-bijak-danrasional-kurangi-bebanpenyakit-infeksi.html. Accesed on 10 May 2017.

Direktorat Jendral Peternakan dan Keehatan Hewan. 2016. Data populasi hewan ternak. https://www.bps.go.id/linkTable Dinamis/view/id/1016. Accessed on April 2017.

Johnson, M., Olaleye, O.N and Kolawole, O.S. 2016. Antimicrobial and Antioxidant Properties of Aqueous Garlic (Allium sativum) Extract against Staphylococcus aureus and Pseudomonas aeruginosa. British Microbiology Research Journal. 14(1): 111.http://www.journalrepository. org/media/journals/BMRJ_8/201 6/Mar/Johnson1412016BMRJ24 095.pdf.

Karlina C.Y., Ibrahim M., dan Trimulyono G. 2013. Aktivitas antibakteri ekstrak herba krokot (Portulaca oleracea L.) terhadap Staphylococcus aureus dan Escherichia coli.E journal UNESA LenteraBio. 2 (1): 8793.http://s3.amazonaws.com/aca demia.edu.documents/328101 62/krokot.PDF?AWSAccessKey $\mathrm{Id}=$ AKIAIWOWYYGZ2Y53UL 3A\&Expires $=1497230042 \&$ Sign ature $=7 \mathrm{aeVCwRdfLN10UPcxIfU}$ y1lLx0Y\%3D\&responsecontentdisposition=inline $\% 3 \mathrm{~B} \% 20$ file name\%3DAktivitas_Antibakteri _Ekstrak_Herba_Krok.pdf.

Karou, D., Savadogo, A., Canini, A., Yameogo, S., Montesano, C., 
Simpore, J., Traore, A. S. 2005. Antibacterial activity of alkaloids from Sida acuta. African Journal of Biotechnology. 4(12), 195-200. http://www.cerbafaso. org/textes/publications/34ph_alk alo.pdf.

Kemal, J. 2014. A Review on the Public

Health Importance of Bovine Salmonellosis. Veterinar Sci Technolo. 5(2):2-10.

Khan, S.J., Roser, D.J., Davies, C.M., Peters, G.M., Stuetz, R.M., Tucker, R., Ashbolt, N.J. 2007. Chemical contaminants in feedlot wastes: concentrations, effects and attenuation. Environment International. $\mathrm{xx}$ : $\mathrm{xxx}-\mathrm{xxx}$. http://www.leap-consulting.com .au/uploads/4/2/9/0/42901589/ch emical_contaminants.pdf.

Kurniawan, I., Sarwiyono., Surjowardojo, P. 2013. Pengaruh teat dipping menggunakan de-kok daun kersen (Muntingia calabura l.) terhadap tingkat kejadian mastitis. Jurnal Ilmu-Ilmu Peternakan. 23(3): 27-31. http://jiip.ub.ac.id/index.php/jiip/ article/view/130.

Kusuma, S.F., Pawening, R.E, and Dijaya, R. 2017. Otomatisasi klasifikasi kematangan buah mengkudu berdasarkan warna dan tekstur. Jurnal Online Unipdu. $\quad 3(1)$ : 17-23. http://www.journal.unipdu.ac.id/ index.php/register/article/ view/576.

Madduluri, S., Rao, K.B., and Sitaram, B. 2013. In vitro evaluation of antibacterial activity of five indigenous plants extract against five bacterial pathogens of human. International Journal of Pharmacy and Pharmaceutical Sciences.5(4):679-684.
http://www.ijppsjournal.com/Vo 15Suppl4/8138.pdf.

Mahanani, R., Praharani, D. and Purwanto, M. 2012. Daya antibakteri ekstrak daun pare (Momordica charantia) dalam menghambat pertumbuhan streptococcus viridans. Artikel Ilmiah Hasil Penelitian Mahasiswa Universitas Jember. http://repository.unej.ac.id/handl e/123456789/59327.

Mahardika, H.A., Sarwiyono dan Surjowardojo, P. 2014. Ekstrak metanol daun kersen (Muntingia calabura L) sebagai antimikroba alami terhadap bakteri Staphylococcus Aureus penyebab mastitis subklinis pada sapi perah. J. Ternak Tropika 15 (2): 15-22. http://ternaktropika.ub.ac.id/inde x.php/tropika/article/view/205.

Manu, R.R.S. 2013. Aktivitas antibakteri ekstrak etanoll daun beluntas (Pluchea indica L.) terhadap staphylococcus aureus, Bacillus subtilis dan Pseudomonas Aeruginose. Jurnal Ilmiah Mahasiswa Universitas Surabaya. 2(1):1-10. http://webhosting.ubaya.ac.id/ j ournalu-

bayaac/index.php/jimus/article/v iew/162.

Murdiati, T.B. 1997. Pemakaian antibiotika dalam usaha peternakan. Wartazoa. 6 (1): 18-22. http://peternakan.litbang.pertania n.go.id/fullteks/wartazoa/wazo6 1-3.pdf? secure $=1$.

Nandhra, I. P., Sudjarwo, E., dan Hamiyanti, A. A. 2015. Pengaruh penggunaan ekstrak daun sirih (Piper betle L.) pada pencelupan telur tetas itik Mojosari terhadap daya tetas dan mortalitas embrio. JIIP. 25 (1): 16-23. http://jiip.ub.ac.id/index.php/jiip/ article/view/194/268. 
Ngajow, M., Abidjulu, J. dan Kamu, V. S. 2013. Pengaruh antibakteri ekstrak kulit batang matoa (Pometia pinnata) terhadap bakteri Staphylococcus aureus secara in vitro. Jurnal MIPA Unsrat Online. 2 (2) 128-132. https://ejournal.unsrat.ac.id/inde x.php/jmuo/article/view/3121.

Nurhalimah, H., N. Wijayanti, dan T.D. Widyaningsih. 2015. Efek antidiare ekstrak daun beluntas (Pluchea indica L) terhadap mencit jantan yang diinduksi bakteri salmonella typhimurium. Jurnal Pangan dan Agroindustri. 3(3): 1083-1094.

http://jpa.ub.ac.id/index.php/jpa/ article/view/231.

Ousallah, M., Cailletm, S., Saucier, L. dan Lacroix, M. 2006. Antimicrobial effects of selected plant essential oils on the growth of a Pseudomonas Putida strain isolated from meat. Meat Science 73: 236-244.

https://www.ncbi.nlm.nih.gov/pu bmed/22062294.

Retnowati, Y., Bialangi, N., and Posangi, N.W. 2011. Pertumbuhan Bakteri Staphylococcus aureus pada media yang diekspos dengan infus daun sambiloto (Andrographis paniculata). Saintek.6(2):1-9.

http://webcache.googleuserconte nt.com/search?q=cache:LN6wcp GZYT4J:repository.ung.ac.id/ge t/simlit_res/1/251/PertumbuhanBakteri-Staphylococcus-AureusPada-Media-Yang-DieksposDengan-Infus-Daun-Sambiloto-

Andrographis-

Paniculata.pdf $+\& c d=2 \& h l=e n \& c t=c \operatorname{lnk} \&$ $\mathrm{gl}=\mathrm{id}$.
Sangi, M., Max, R.J. Runtuwene, E. I., Herny, Simbala and M. A., Makang, V. 2008. Analisis fitokimia tumbuhan obat di Kabupaten Minahasa Utara. Chem. Prog. 1 (1) :47-53. https://ejournal.unsrat.ac.id/inde x.php/chemprog/article/view/26.

Sabir, A. 2005. Aktivitas antibakteri flavonoid propolis Trigona sp. terhadap bakteri streptococcus mutans (in vitro). Maj. Ked. Gigi. (Dent. J.). 38 (3): 135-141. http://journal.unair.ac.id/filerPD F/DENTJ-38-3-08.pdf.

Soedibyo, 2004. Pengaruh pemberian bawang putih terhadap total bakteri feses ayam. http://digilib.litbang.deptan.go.id /repository/index.php/attachment 136342.pdf. Accessed on 20 February 2017.

Soeripto and Poeloengan, M. 1991. Isolasi bakteri dari embrio ayam broiler yang tidak menetas dan sensitivitasnya terhadap beberapa antibiotika. Penyakit Hewan. Vol. 23(41)1991. p. 11-14.

Solomon, W. G., Ugoh, S. and Mohammed, B. (2014). Phytochemical screening and antimicrobial activities of Annona muricata (1) leaf extract. American Journal Biology Chemistry Pharmaceutical Sciences. Vol. 2(1), 1-7. http://www.ajbcps.com/AJBCPS _Vol.\%202,\%20No.\%201,\%20J anuary $\% 202014 /$ Phytochemical \%20Screening.pdf.

Suganda, T., Yulia, E., Widiantini, F and Hersanti. 2016. Intensitas penyakit blas (Pyricularia Cav) pada padi varietas ciherang di lokasi endemic dan pengaruhnya terhadap kehilangan hasil. Jurnal Agrikultura. 27(3): 154-159. 
jurnal.unpad.ac.id/agrikultura/art icle/download/10878/4861.

Tisdell, C.A., Harrison, S.R., and Ramsay, G.C. 1999. The economic impacts of endemic diseases and disease control programmes. Rev. sci. tech. Off. int. Epiz. 18 (2):380-398.

https://www.ncbi.nlm.nih.gov/pu bmed/10472675.

Widyawati , P.S. and Budiant, T.D.W. 2014. Difference of solvent polarity to phytochemical content and antioxidant activity of pluchea indicia less leaves extracts. International Journal of Pharmacognosy and Phytochemical Research. 6(4): 850-855. http://impactfactor.org/PDF/IJPP R/6/IJPPR,Vol6,Issue4,Article2 9.pdf.

WHO. 2016. Antrimicrobial Resistance. www.who.int/mediacente/factsh eets/fs194/en/. Accessed on 10 May 2017.
Wiyanto, D. B. 2010. Uji aktivitas antibakteri ekstrak rumput laut Kappaphycus alvarezii dan Eucheuma denticullatum terhadap bakteri Aeromonas hydrophila dan Vibrio harveyii. Jurnal Kelautan. $\quad 3 \quad$ (1):1-16. http://journal.trunojoyo.ac.id/jur nalkelautan/article/view/837.

Zamzamy, S. P., Sudjarwo, E., Hamiyanti, A. A. 2015. Pengaruh Penggunaan Ekstrak Daun BeLuntas (Pluchea indica less.) Pada Pencelupan Telur Tetas Itik Mojosari Terhadap Daya Tetas Dan Mortalitas Embrio. Fakultas Peternakan. Universitas Brawijaya, Malang. http://download.portalgaruda.org /article.php? article $=327496 \& \mathrm{val}$ $=4696 \&$ title $=$ PEMBERIAN $\% 20$ EKSTRAK\%20DAUN\%20BEL UNTAS\%20. 